\title{
ANALYSING CULTURAL ASPECTS IN EFL TEXTBOOKS: A SKILL-BASED ANALYSIS
}

\author{
Antonio Raigón-RodrígueZ \\ Universidad de Córdoba \\ antonio.raigon@uco.es
}

\begin{abstract}
In teaching/learning English as a Foreign Language, one of the goals is to develop interculturally competent citizens. Consequently, culture must play a major role. As textbooks are carriers of cultural information, special attention should be paid to the cultural content of textbooks. This article compares the cultural content of six B2-level textbooks for English language teaching in Spain. The editions range from 1992 to 2013 and were distributed by well-known publishing houses. The purpose of the study is to identify whether cultural content (general, big 'C' and small ' $C$ ') has been incorporated in newer editions to answer to globalised needs and, secondly, to determine which skill is used preferably to do so. The author has adopted a culture learning model developed by Lee (2009) and design a three-fold cultural checklist. Then, content analysis methodology (Krippendorff 2004) has been used to quantify qualitative data. Data suggest that even in newer editions, products, artefacts and external behaviours are used more frequently when trying to portray a specific culture, leaving aside general cultural content and internal culture (small ' $c$ '). It was also found that skill usage is different depending on the type of culture learning.
\end{abstract}

Keywords: Culture teaching/learning, EFL teaching/learning, textbooks, intercultural learning, big ' $\mathrm{C}$ ', small ' $\mathrm{C}$ '. 


\title{
UN ANÁLISIS MULTI-COMPETENCIAL DE LOS ELEMENTOS CULTURALES EN LOS LIBROS DE INGLÉS COMO LENGUA EXTRANJERA
}

\begin{abstract}
RESUMEN. En la enseñanza/aprendizaje de inglés como lengua extranjera, uno de los objetivos primordiales es desarrollar ciudadanos interculturalmente competentes. Como consecuencia, la cultura ba de jugar un papel primordial en el aula. Al ser los libros de texto los que transmiten la información cultural, se debe prestar especial atención al contenido cultural que albergan. Este trabajo compara dicho contenido en seis libros de texto de nivel B2 utilizados en España. Se trata de libros de reconocidas editoriales publicados entre 1992 y 2013. El propósito de este estudio es identificar si el contenido cultural (general, cultura visible e invisible) ba ido siendo incorporado en las ediciones más recientes para responder a las actuales necesidades globalizadas y, en segundo lugar, cuál es la destreza comunicativa en la que preferiblemente se realiza esta transmisión de contenidos. El autor ha adaptado el modelo de análisis cultural desarrollado por Lee (2009) and ha desarrollado un listado tridimensional. Posteriormente, se ha utilizado la metodología de análisis de contenido (Krippendorff 2004) para cuantificar los datos cualitativos.
\end{abstract}

Palabras clave: Aprendizaje/enseñanza cultural, aprendizaje/enseñanza de inglés como lengua extranjera, libros de texto de inglés como lengua extranjera, aprendizaje intercultural, cultura visible e invisible.

Received 17 November 2017

Revised version accepted 9 February 2018

\section{INTRODUCTION}

Globalization has made intercultural encounters more frequent than ever. This new context requires an answer in the EFL classroom. Learners need to acquire knowledge about the target language community to later reflect on their own culture (McKay 2002: 83). This has led to a discussion among language teaching researchers regarding the new student training needs (Baker 2012; Byram 2008; Kramsch 1993; Larrea-Espinar 2015; Mendez-García 2005; Risager 2011). In order to communicate interculturally, apart from knowledge, students need to develop skills and attitudes (Byram 1997).

Even before the edition of the Common European Framework of Reference (CEFR), it was clear that culture played a major role in language learning. However, this document does not establish specific descriptors for the cultural component acquisition, even though it endorses and recognises its importance.

This study uses a checklist designed by the author to analyse the cultural content of six language textbooks. The main objective is to identify whether 
cultural content (general, big ' $C$ ' and small ' $c$ ') has been incorporated in newer editions with the purpose of answering to globalised needs and which skill is preferably used to do so.

\section{THE EVOLUTION OF CULTURE IN ENGLISH LANGUAGE TEACHING}

For many years, the relation between culture and language learning has been dealt with extensively -for a review on the most important works in the field, see Risager (2011). For decades, many scholars have expounded the unbreakable relation between culture and language and its influence on language learning: 'Language and culture are not separate, but are acquired together, with each providing support for the development of the other' (Mitchell and Myles 2004: 235). Weninger and Kiss (2013) identify three stages in dealing with culture. In the first one (1955-1990's), culture was conceived as a series of facts to be learnt about the target language culture. These were easily visible events, which Kramsch named 'facts, food, folklore and festivals' (1993: 24). These aspects represent the big 'C' aspects of culture (Peterson 2004) and are explicitly learned.

The link between language and culture is renewed and reinforced in the second stage (the 1990's). Culture is a key component of language acquisition as it is shown in the notion of intercultural communicative competence (ICC) (Byram 1997). He identifies the basic components of ICC: attitudes (curiosity, openness, readiness to suspend one's own beliefs, etc.), knowledge (about social groups and their products), skills of interpreting and relating (a document or event from another culture to one's own), skills of discovery and interaction, critical cultural awareness/political education (as a tool for practices and products evaluation). Thus, within the five-savoir approach, critical cultural awareness represents the need to understand not only the behaviour but also the values and beliefs of other cultures (and our own). Values and beliefs underlie behaviour and are considered the small 'c' aspects of culture, essential to understand the ways of thinking of a society. In this sense, students need to be prepared to confront ambiguities and to be 'attuned to the potential multiplicity of ways of construing utterances in discourse depending on the sociocultural context of the interaction' (McConachy and Hata 2013: 301). The advent of the communicative approach in English language teaching brings together these ideas. However, Holliday (1999) poses a question regarding the nature of the concept culture and its implications in the teaching of languages. In his frame, 'small' cultures relate to cohesive behaviour of any social grouping, which are not necessarily contained in national 'large' cultures and are non-essentialist. In his opinion, there seems to exist a confusion regarding 'small' cultures, which are seen by both academics and non-academics 
alike as a metaphor of the national-ethnic concept of culture ('large', in his words). Nevertheless, these 'small' cultures are not contained in 'larger' entities but transcend them and "constitute a seamless mélange which stretches across national boundaries" (1999: 240). Holliday (ibid., 243) also states that the notion of 'large' culture answers to a Western need to create 'imagined communities', concept introduced by Benedict Anderson in the 1980's. The 'large' culture paradigm also fails to depict the world as "an increasing cosmopolitan, multi-cultural place where cultures are less likely to appear as large coherent geographical entities (ibid., 244). An example of 'small' culture as defined by Holliday is our neighbourhood, a real (as opposed to 'imagined') community, which can be divided in subsequent groups and cultures. This non-essentialist view strengthens our claim to underline the importance of developing skills and attitudes, rather than transmitting mere facts and knowledge.

The last stage is reached at the turn of the new century and shows a transnational approach. As we live in a globalised world, the teacher should help to educate "a critically reflective mind that can tell the difference between real and unreal, between information and disinformation, between ideas and ideologies" (Kumaravadivelu 2008: 164). Thus, concepts like 'global cultural consciousness' (ibid., 164) and 'intercultural citizenship' (Byram 2008: 157) mean that students should be conscious citizens in our society. Since his earlier works, Byram has perceived the role of the language teacher as transcending the transmission of knowledge: "the responsibility of language teachers for introducing learners to another culture involves them in decisions which are educational and political" (1988: 17). In his reviewed version, ICC becomes intercultural citizenship, which combines the aims of language teaching and citizenship education (2008). He states that language teaching must aim at including moral and political education to lead action in the world.

\section{CULTURE IN TEXTBOOKS}

Lately there has been a renewed interest on the topic of how culture is represented in textbooks (Weninger and Kiss 2015), not only in EFL, but also regarding which culture(s) should be included (Shin, Eslami and Chen 2011). As far as cultural EFL textbook analysis is concerned, Lee (2009) studied 11 secondary school conversation books, Wu (2010) revised a complete series of higher education EFL textbooks (College English) and Yuen (2011) analysed the presence of foreign cultures in several Hong Kong high school textbooks. Following a semiotic approach, Weninger and Kiss (2013) examined local Hungarian textbooks. Finally, in Spain, we must highlight the work of Méndez-García (2005) with High School 
materials and Larrea-Espinar (2015) selecting B1 books for adults and youngadults. The present study adds a synchronic perspective and an attention to skill distribution, as well as a larger sample if compared to most previous works.

As for the question of what culture or cultures should be represented in textbooks, Saville-Troike (2003: 15) points out that it depends on the social context in which that language is being learnt and in which it will be used. Crystal (2008) states that English is and has been for some time more extensively used in the expanding circle (i.e. not native speakers of the language with completely different cultural backgrounds). Thus, "if English is to be used as a medium for intercultural communication, the cultural content included in teaching materials should not focus mainly on the cultures of English-speaking countries" (Yuen 2011: 464). In this sense, it proves more appropriate and practical to foster students' cultural knowledge by having recourse to various cultures and, in turn, developing intercultural competence: "Learners should begin by realising and understanding their own culture, respecting others' cultures and being culturally sensitive" (Lai 2014: 6).

In relation to the analysis of culture in textbooks, it has generally been examined using models or assessment checklists. Byram and Esarte-Sarries (1991) and Risager (1991) used a four-dimension model. Then, Byram and Morgan (1994: 51) proposed thematic categories to examine the cultural content of textbooks, ranging from social identity and groups, social interaction, moral and religious beliefs, to national history and stereotypes. A few years later, Paige et al. (1999) designed a conceptual model to combine the teaching/learning of language and culture. Their model stems from previous works by Byram (1997) and Kramsch (1993) and develops the idea that complete culture learning requires the acquisition of general and specific culture. The general aspect of culture implies the acquisition of attitudes, skills and knowledge that are widespread and can be transferred to other cultures; the specific culture covers both big ' $\mathrm{C}$ ' and small ' $\mathrm{C}$ ' aspects related to a particular community or group. Lee (2009) turned this theoretical model into a practical one adding a classification by themes. He also classified the occurrences by formal presentation types - dialogue, image or activity - depending upon how the cultural aspect was presented in the book. Regarding culture in general, he suggested 16 themes, divided in three sections (knowledge, behavior and attitude). Some theme examples are, respectively, the self as a cultural being, intercultural communicative competence or positive attitude towards cultural learning. As long as specific culture is concerned, to acquire aspects of big 'C' Culture, Lee used 22 categories, for example, literature, education, regions or government and politics. Referring to aspects of small 'c' culture he sketched 26, such as fairness, materialism, experimental or self-reliance. 
In turn, the author of this study drew on Lee's model to devise a more functional tool for recollection of data. To that aim, the number of categories proposed by Lee are simplified and reduced combining certain themes that may be considered as falling within the same spectrum (for example, 'Infrastructure/ metropolitan' and 'Traffic/transportation' in big 'C' culture); we also eliminated categories that proved to be redundant or difficult to identify in a textbook due to being excessively specific ('High involvement' and 'Experimental' in small 'c' culture, to give but two examples). Our checklist includes a categorization of occurrences according to the skills involved (reading, listening, speaking or writing). The author believes that these changes help to provide a more functional model without jeopardising effectiveness or rigour.

As for the approaches, many techniques have been used in the analysis of textbooks. For our study, we have used content analysis to quantify qualitative data.

\section{METHODOLOGY}

\subsection{RESEARCH QUESTIONS}

The goal of this study is to determine whether cultural content (general, big ' $C$ ' and small ' $\mathrm{C}$ ') has been incorporated in newer editions to answer to globalised needs or not. As a secondary objective, we will also consider which skill is used preferably to do so. With these aims, we have established the following research questions:

1. Are newer editions more aware of cultural learning in its different dimensions?

2. Are different skills used for different cultural learning aspects?

These two questions will give information regarding two key aspects: firstly, we will be able to determine if publishing houses are aware of cultural content in their texts and are responding accordingly; secondly, the skills used show the type of learning implemented and the degree of student involvement.

\subsection{SAMPLE}

A content analysis of six EFL textbooks has been conducted. These B2 level books were written for adults and young adults and are used primarily in university language centres. Even though Spanish university students require only a B1 level to obtain their degree, B2 is what they need in order to have access to the most common foreign-study grants (Erasmus + student mobility for studies or placements, for example). 
We have selected books from the most important EFL publishing houses in Spain (Oxford University Press, Cambridge University Press, MacMillan and Heinemann).

Table 1. Textbooks used in the study.

\begin{tabular}{|l|l|c|}
\hline Straightforward. Second Edition & MacMillan Education & 2012 \\
\hline English Unlimited & Cambridge University Press & 2011 \\
\hline New English File Upper-intermediate. & Oxford University Press & 2008 \\
\hline English File Upper-intermediate. First Edition & Oxford University Press & 2001 \\
\hline Inside Out Upper Intermediate & MacMillan Education & 2001 \\
\hline Highlight Upper Intermediate & Heinemann ELT & 1992 \\
\hline
\end{tabular}

Their publication dates range from 1992 to 2012. We believe this synchronic element may provide some significant information regarding the evolution of cultural learning in EFL books.

\subsection{DATA COLLECTION AND ANALYSIS}

As we need to quantify qualitative data, we have used content analysis, which is 'a research technique for making replicable and valid inferences from texts (or other meaningful matter) to the contexts of their use' (Krippendorff 2004: 18).

The data language is a three-fold checklist that stems from the previous work of Paige et al. (1999) and Lee (2009).

Table 2. Culture checklist.

\begin{tabular}{|l|l|}
\hline CULTURE IN GENERAL \\
\hline Knowledge: & $\begin{array}{l}\text { Cultural learning } \\
\text { Cultural adjustment stages (Shock) } \\
\text { Cultural identity }\end{array}$ \\
\hline $\begin{array}{l}\text { Behaviour } \\
\text { Strategies: }\end{array}$ & $\begin{array}{l}\text { Culture learning or dealing with Intercultural stress } \\
\text { Cultural adaptability }\end{array}$ \\
\hline Attitudes: & $\begin{array}{l}\text { Positive attitude toward cultural learning } \\
\text { Positive attitude toward cultural differences }\end{array}$ \\
\hline BIG C CATEGORIES \\
\hline Ethnic groups \\
\hline Geography/history/politics/regional variations \\
\hline
\end{tabular}




\begin{tabular}{|l|}
\hline Arts/crafts/monuments/ historical sites/ \\
\hline Literature, films, music and mass media/Icons/Celebrities \\
\hline Currency/shopping/market/industry/business \\
\hline Urban life/infrastructure/housing/transportation \\
\hline Education \\
\hline Dress-style \\
\hline Food \\
\hline Festivals/celebrations/holidays/ceremonies \\
\hline Social customs \\
\hline Leisure/sports \\
\hline Family \\
\hline Non-verbal communication (personal space, oculesics, haptics...) \\
\hline SMALL c CATEGORIES \\
\hline Individualism/collectivism \\
\hline Equality \\
\hline Fairness \\
\hline Competition \\
\hline Materialism \\
\hline Confrontation \\
\hline Novelty oriented (newer is better) \\
\hline Self-improvement \\
\hline Nurture (up-bringing, education) \\
\hline Time \\
\hline Level of formality \\
\hline Communication styles: direct vs. indirect \\
\hline Rules-regulation oriented \\
\hline Male-oriented \\
\hline Result-oriented \\
\hline
\end{tabular}

In order to record cultural incidences (understood as instances where cultural information/values/behaviours are transmitted), we agree with Weninger and Kiss (2013: 696) in considering activities as the unit of examination in reporting cultural incidences, mainly because cultural learning cannot occur by mere observation of pictures or the description of facts. This approach enhances traditional content analysis, which ignores the multimodal nature of the textbook. However, we have not follow Chen's semiotic analysis (2010), who concentrates on images as means to develop emotion and attitude goals. According to this author, "images in textbooks play an important role in realizing a great variety of emotion and attitude curriculum goals" (ibid., 72). Although its findings are interesting, we have not included a multimodal analysis of this kind, and have rather used the activity as unit of examination as explained above. 
One of the main criticisms regarding content analysis is the subjective nature of the data collection process (Krippendorff 2004). This shortcoming has been addressed. Both data collection and analysis were carried out by the writer and reviewed by another member of the English department, also specialising in cultural studies and language learning. Thus, we guarantee the study's reliability and replicability.

For the purposes of analysing the cultural learning content, only the textbooks themselves were studied, ignoring any complementary course material such as CD-Roms, workbooks, websites, and online activities.

\subsection{FINDINGS}

\section{Research question 1}

Culture in General. Activities related to the development of behaviour and attitudes are very scarce in the total occurrences of the six textbooks (only 5 each). However, we find 46 related to knowledge acquisition (84.1\% of the total). The concept of cultural identity is the most recurrent, while strategies for cultural adaptability have been registered just once on page 117 of English Unlimited. The students are provided with information and advice regarding the kind of expected behaviour when looking for a job in countries as diverse as Venezuela, Ireland, China or England. If they decide to look for a job abroad, they are provided with specific pieces of advice (research local customs, topics of conversation, nonverbal communication or how to address a person at a first meeting). Also, at the end of the unit, the concept of professional culture is introduced (cultural identity).

Total Culture in general incidences

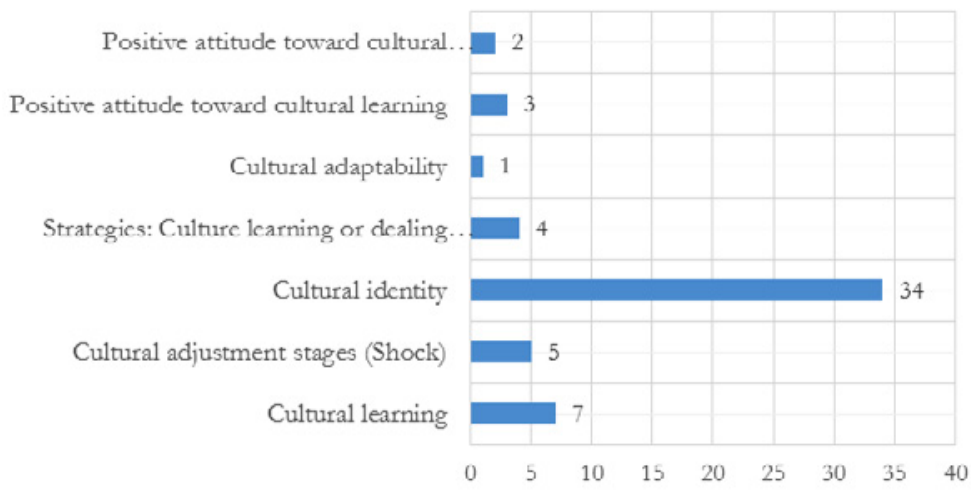

Figure 1. Culture in General occurrences by categories. 
The importance given to this dimension is very different in the different texts as can be seen in the graph.

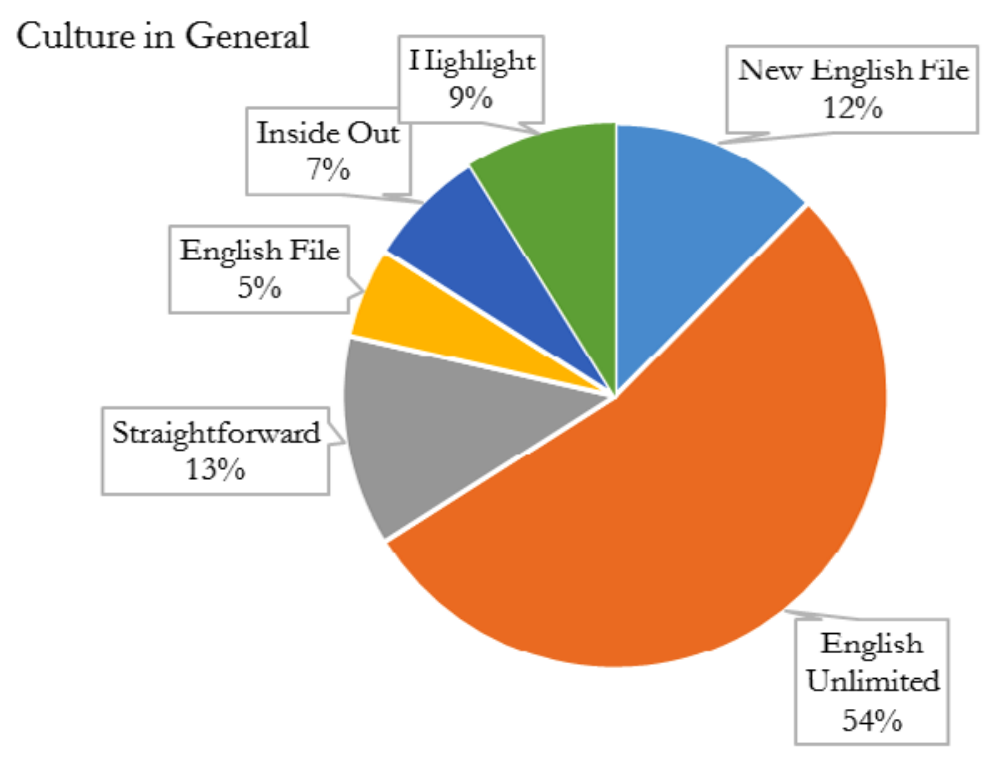

Figure 2. Culture in general occurrences by textbooks.

English Unlimited is, by far, the textbook where more occurrences are recorded (54\%). It is worth mentioning that the English File newer edition increases 7\% and that the three older editions, Highlight, Inside Out and English File only work one item, 'Cultural identity', on 5, 4 and 3 occasions respectively. Straightforward (not the same series but the same publishing house) scores $6 \%$ higher than Inside Out, edited 11 years earlier.

Big ' C' Culture. In the graphs below, the distribution of the 231 incidences in the big ' $\mathrm{C}$ ' specific culture dimension can be observed, both in the different books and the distribution per items.

English Unlimited more than doubles New English File ( $3^{\text {rd }}$ ed.) in occurrences. Highlight and Straightforward are the two texts that contain fewer cultural references.

If we pay attention to the incidences per item, we can see that 'Literature, films, music and mass media/ Icons/ Celebrities' references (20.3\% of the total), followed by 'Social customs' (13.4\%). 'Family', 'Non-verbal communication', 'Leisure/sports' and 'Dress-style' are the least registered items. 
Total: Big C ocurrences

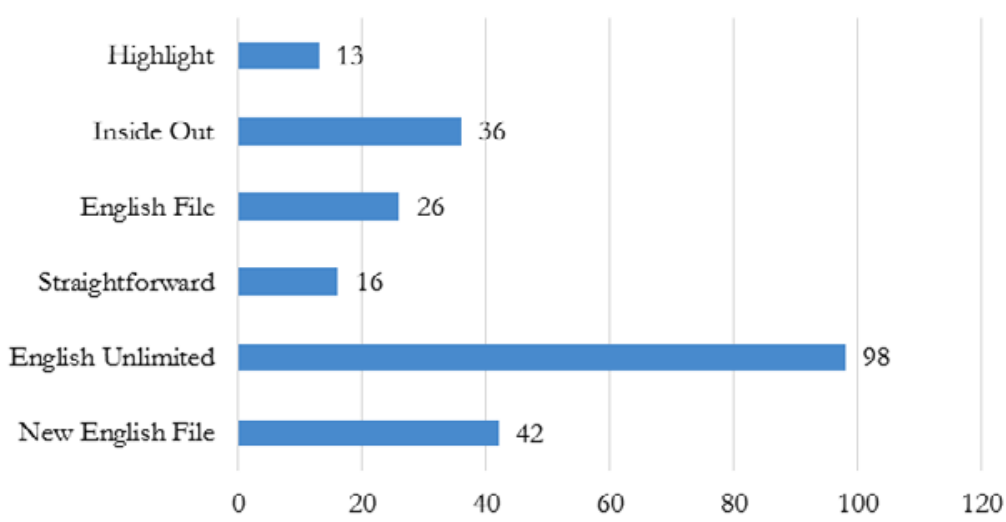

Figure 3. Big 'C' occurrences by textbooks.

\section{Big C Categories}

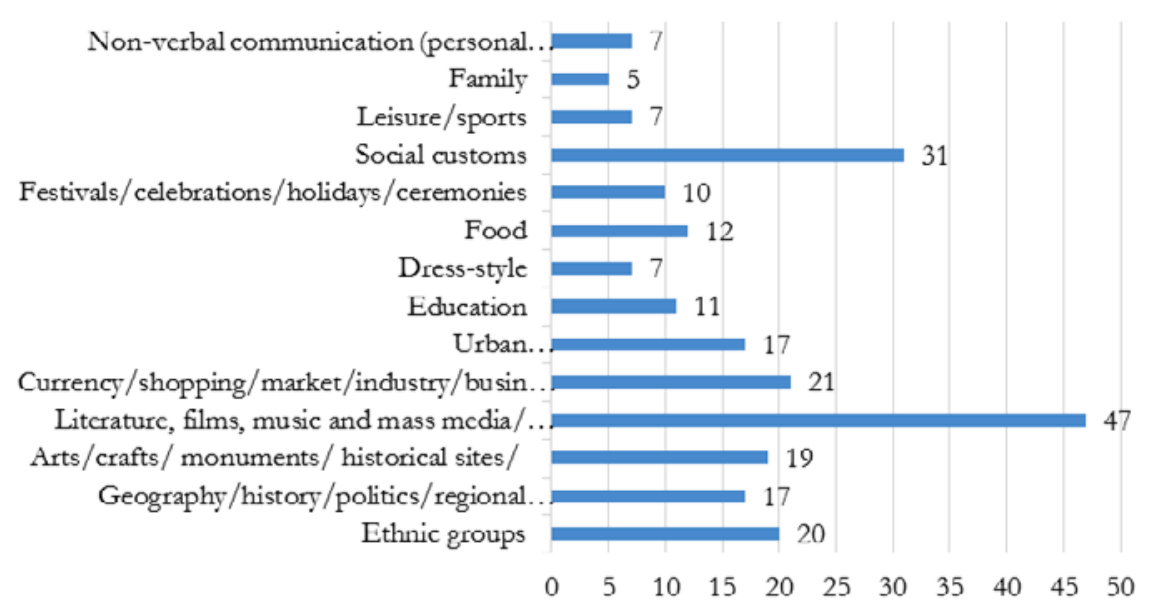

Figure 4. Big 'C' occurrences by categories.

English Unlimited presents the best range regarding item representation, with all the categories covered. Highlight scores lowest with 7 unrecorded items, followed by English File (6) and Straightforward, New English File and Inside Out (4).

Small 'c' Culture. In the graphs below, the distribution of the 100 incidences in the small 'c' specific culture dimension can be observed, both in the different books and the distribution per items. 


\section{Total: Small c occurrences}

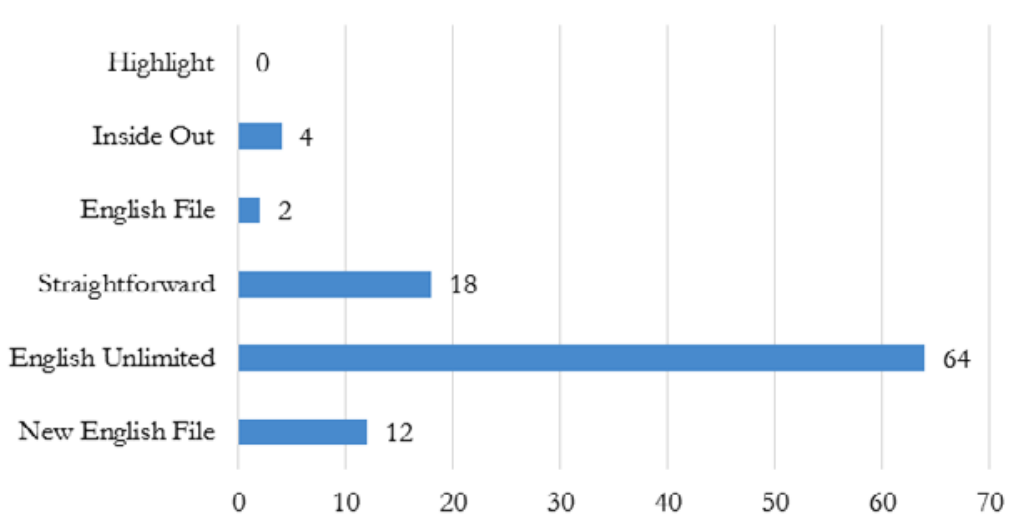

Figure 5. Small 'c' occurrences by textbooks.

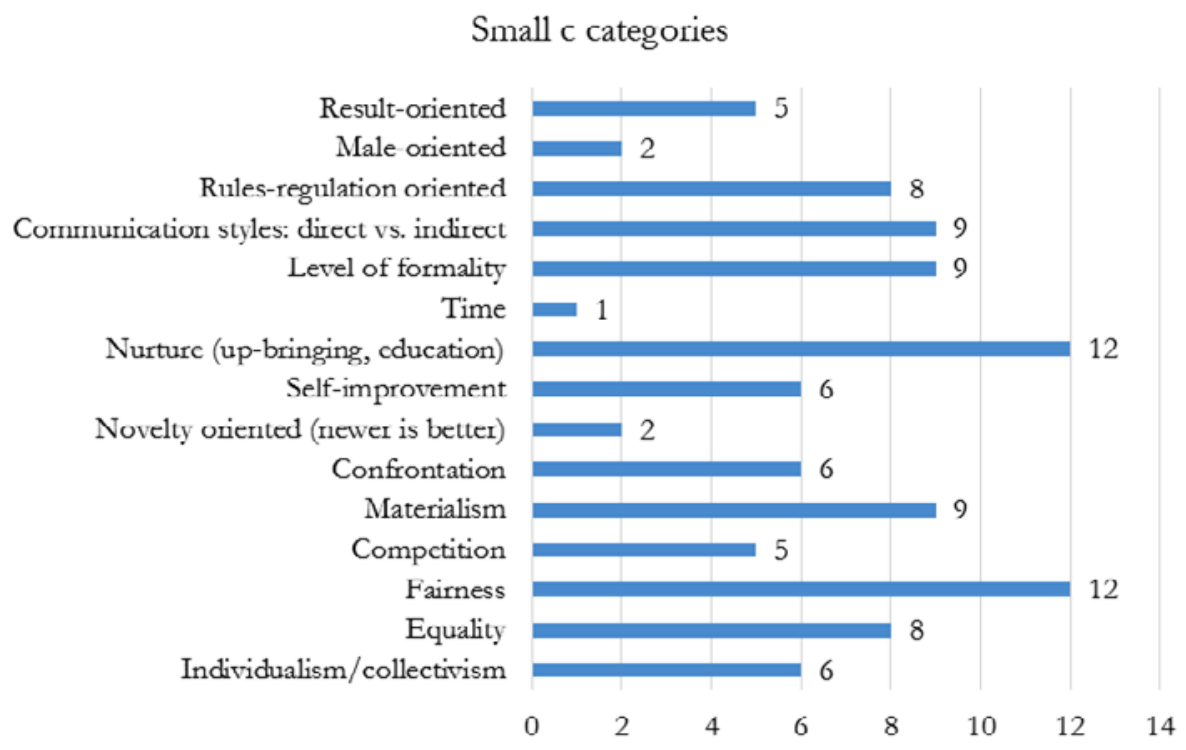

Figure 6. Small 'c' occurrences by categories.

English Unlimited has the highest score in the small 'c' occurrences as well (64 out of a total of 100, which almost quadruplicates the second one, Straightforward). Even discarding it, newer editions seem to be paying more attention to this dimension, which is almost completely disregarded in older editions (2001 and earlier). 
With a mean of 6.7 occurrences per item, 'Rules-regulation oriented', 'Communication styles', 'Levels of formality', 'Nurture', 'Materialism', 'Fairness' and 'Equality' score over it. Once more, English Unlimited presents the best range, leaving behind just two items ('Time' and 'Male-oriented').

In summary, the number of total cultural occurrences recorded is 387 (Culture in general 56, big 'C' 231 and small 'c' 100). Big 'C' occurrences being $59.7 \%$ of the total is consistent with prior studies (Raigón-Rodríguez and LarreaEspinar 2015), reinforcing the idea that products, artefacts and specific cultural behaviours are the most pervasive items in textbooks when it comes to culture.

\section{Research question 2}

As for the relation between cultural learning and the skills used for each dimension, the graphs below show the total number of occurrences distributed among the four skills.

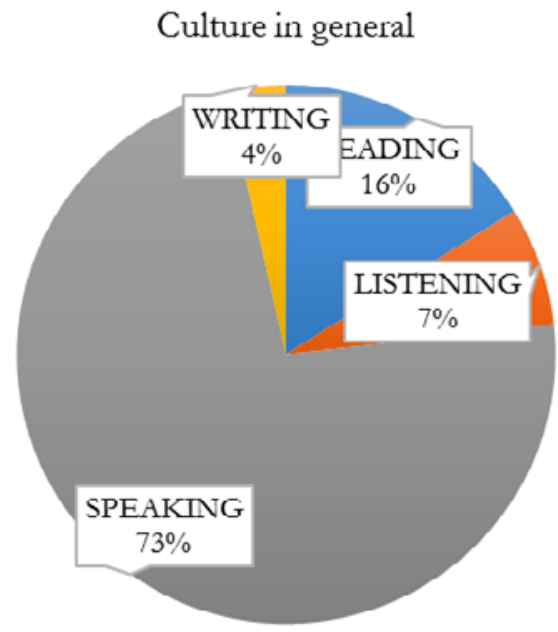

Figure 7. Culture in general occurrences by skill.

It is noticeable that speaking is the most used skill for cultural learning in the Culture in general dimension. Almost 3 out of 4 incidences are related to oral production. However, both dimensions related to specific culture learning (big ' $\mathrm{C}$ ' and small ' $\mathrm{C}$ ') are highly linked to receptive activities: reading (44\% and 36\% respectively) and listening (40\% and 41\%). Only 16\% and 23\% are occurrences of productive skills activities. 


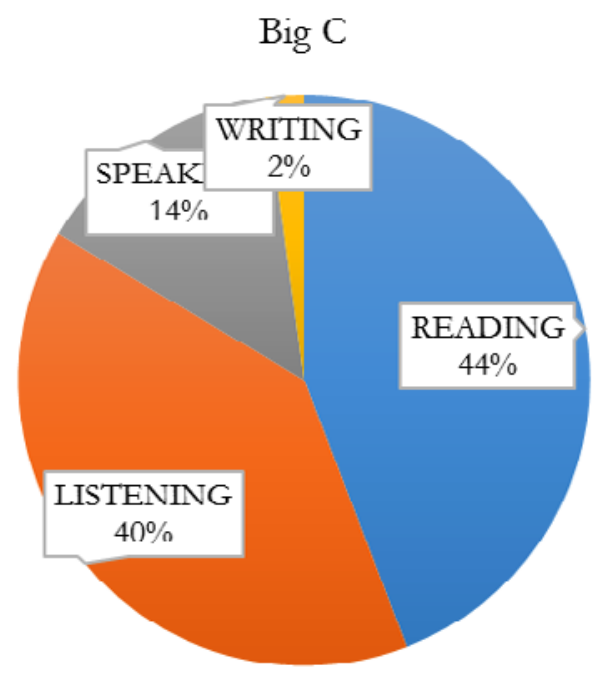

Figure 8. Big 'C' occurrences by skill.

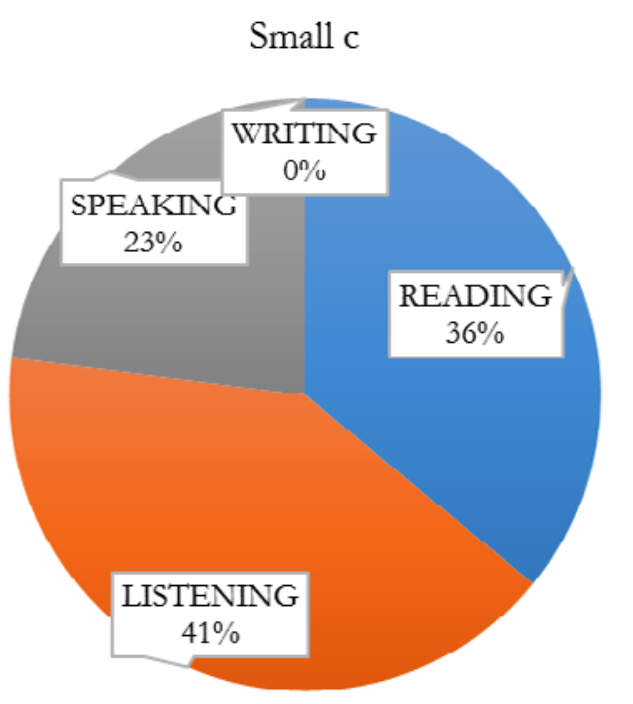

Figure 9. Small 'c' occurrences by skill.

\section{DISCUSSION OF RESULTS}

As expected, the number of cultural learning occurrences is quite unevenly distributed among dimensions, where anecdotal knowledge about specific cultures 
(big 'C') is recorded 231 times, representing almost 60 percent of the total. A much lesser weight is given to beliefs and specific culture world views (small 'c'), with one fourth of the total. The acquisition of a certain culture or cultures should not be the main goal but rather developing students' abilities and behaviours that allow them to interact in multicultural environments (Byram 2014). Consequently, it is worrying that Culture in general only reaches $14.5 \%$ of the total. This poses a problem for students' cultural training in our view.

Table 3. Total occurrences by textbooks.

\begin{tabular}{|l|l|l|l|}
\hline Textbooks & Culture General & Big C & Small c \\
\hline Straightforward. Second Edition (2012) & 7 & 16 & 18 \\
\hline English Unlimited (2011) & 30 & 98 & 64 \\
\hline New English File Upper-intermediate (2008) & 7 & 42 & 12 \\
\hline English File Upper-intermediate (2001) & 3 & 26 & 2 \\
\hline Inside Out Upper Intermediate (2001) & 4 & 36 & 4 \\
\hline Highlight Upper Intermediate (1992) & 5 & 13 & 0 \\
\hline
\end{tabular}

As we can observe from the figures, we can only establish a clear relation between publication dates and occurrences in the small 'c' dimension. This side of cultural learning, almost invisible in the older editions, is more represented in the newer ones, although unevenly. English Unlimited almost doubles the rest of the other books combined.

On the contrary, if we take aside English Unlimited, which can be defined as a rara avis, we cannot sustain that generally there is an increased number of occurrences in newer editions regarding Culture in general. With a mean of 5.2, Culture in general is underrepresented in all the textbooks. Once more, it should not be left unmentioned that English Unlimited's 30 recorded activities cover all the items in our checklist.

Besides, big 'C' representation shows differences, but these do not fall into a chronological pattern, since the newest and the oldest book register almost the same number of occurrences (16 and 13). If we pay attention to big 'C' specific culture, it is revealing how culture is so underrepresented in a 2012 textbook such as Straightforward (16), with only three more occurrences than Highlight, published 20 years before. Moreover, Straightforward shows an anecdotic and superficial treatment of cultural learning. An example to illustrate this can be found in unit 11B, 'South is up'. This unit shows a picture of the world map 'upsidedown'. Instead of using this to discuss deeper issues of Culture in general such 
as ethnocentrism (e.g. the place of Europe and the rest of the world on Western maps), the speaking activities ask students to discuss what maps they have at home and how often they use them.

By contrast, English Unlimited represents an attempt to really entwine culture and language, going deeper, as can be seen in its seven 'Across cultures' units. One of the best examples can be found on page 37, 'Special occasions' where a Brit talks about Bonfire Night and a Pole talks about weddings in her country. This is an interesting case because the topic moves away from the stereotype alone and also from Anglo-Saxon culture. The students have a chance to listen to the characters, to later talk about their own opinions and describe a special occasion from a culture, either their own or another. Other topics dealt with similarly in this textbook are 'Aspects of culture' (21), 'Ways of communicating' (53) or 'Rights and obligations' (85).

Regarding the big ' $\mathrm{C}$ ' dimension, items are very unevenly represented, tending to the touristic and stereotypical vision of specific cultures. Again, English Unlimited proves to be more complete in this area, covering all the big ' $\mathrm{C}$ ' items while Highlight has the poorest range. Hence, we cannot establish a correlation in this dimension between publication date and cultural occurrences here, but rather describe them as individual differences. Finally, we should mention obvious differences in the two English File series editions, which increase the number of incidences in all dimensions ( 3 to 7 in Culture in general, 26 to 42 in big ' $\mathrm{C}$ ' and 2 to 12 in small ' $c$ '). This proves a raised cultural awareness in this particular publishing house.

Regarding our second research question, data reveal differences in skill usage in the different dimensions. Productive skills represent $77 \%$ of the Culture in general occurrences, while just $16 \%$ in big 'C' culture and $23 \%$ in small 'c'.

In order to develop Culture in general learning, a greater involvement on the part of the student is needed. This involvement is produced by means of speaking and discussion activities in which they need to evaluate their own culture, suspend their beliefs and interpret alternate cultural visions. Examples of this can be found in English File (10, 48 and 110), where the students discuss their own cultural stereotypes or how their own culture is influenced by America. The later edition, New English File, moves around the same topics: national stereotypes and own customs (20, 23 or 91). Highlight introduces discussion questions like 'How do people in your country live now?' (10), 'Describe a typical meal in your country' (1), which is a rather shallow attempt at own's culture awareness. Inside Out treats this dimension similarly, as can be observed on pages 98 or 104. Straightforward uses 'Did you know?' texts about some cultural aspect to introduce discussion 
questions regarding the students' own culture (39 or 99). English Unlimited stands out again, not being constricted to the students' own cultural identity, as can be observed on page 65 ('Critical incidents'), where cross-cultural misunderstandings are dealt with. Positive attitudes are also developed (as can be seen on page 21).

This tendency towards productive skills is reverted in the specific culture learning (big ' $\mathrm{C}$ ' and small 'c'). 84\% and 77\% are listening or reading activities, which proves the unidirectional type of cultural learning which is promoted by these textbooks. This reinforces the idea that students are mainly given information (knowledge) but not interpreting tools. On the contrary, if our intention is the development of behaviours and attitudes, a more interactive and multidirectional approach must be sought. Moreover, this is also the case when we look closely at the recorded activities in Culture in general. Abilities and strategies development are hardly ever dealt with (just $17.9 \%$ of the total occurrences in this section).

\section{CONCLUSIONS}

It seems that cultural learning's importance is highlighted everywhere but generally neglected when it comes to be put into practice. As we have seen, apart from English Unlimited, newer editions pose an insufficient effort since they merely decorate their texts with plenty of anecdotal cultural facts. Sometimes, that is not even the case. $56.7 \%$ fewer occurrences in small ' $\mathrm{C}$ ' than in big ' $\mathrm{C}$ ' consolidates the idea that products, artefacts and external behaviours are used more frequently when trying to portray a specific culture. It is obvious that teaching the beliefs and worldviews shared by a particular community poses a greater difficulty. In most cases, we are just able to perceive a reified version of different cultures, 'large' stereotypical cultures in Holliday's words (1999), where a much more flexible and complex phenomenon should be tried to be portrayed. Materials should be designed to develop discovery, accommodation and negotiation skills, what Baker presents as intercultural awareness (ICA), a concept that has evolved from cultural awareness (CA), a 'non-essentialist' alternative. This would allow a dynamic approach to culture, perceived as 'something freer and more fluid' (Baker 2012: 64), much like Kramsch's influential notion of the 'third place' (1993). This is clearly not the case in the analysed textbooks, where most of the cultural learning deals with stereotypical behaviours and products.

Language learning, besides its obvious uses, must be a tool for social change and cultural understanding. Introducing different cultures in the classroom is a step towards intercultural understanding and peace, in Byram's words, 'a springboard for political action' (2014: 18); however, stereotypical facts about specific cultures will not bring about this action. 
Although an improvement in some areas can be observed, there needs to be an increase in the effort to integrate cultural learning in textbooks, particularly in the Culture in general and small 'c' dimensions. 'Since textbooks are institutionally sanctioned artefacts [...] learners are likely to treat these textbooks as carriers of truth' (Weninger and Kiss 2015: 54). For this reason, textbook writers should move away from Kramsch's 'four F's' (1993) and the mere anecdotic knowledge about a particular culture. Even though it can be stated, based on the recorded data, that this movement has already started, a greater effort on the development of the last two is greatly needed. Regarding skill usage, we have been able to prove that the development of culture in general abilities and behaviours must be dealt with by productive skills, where the student can cease to be a passive subject in the process. Only this change in roles and training can prepare our students for multicultural interaction and intercultural communication. We are faced with the fact that if textbooks are unable to provide this training, different tools will have to be introduced in the classroom.

\section{REFERENCES}

Baker, W. 2012. "From cultural awareness to intercultural awareness: culture in ELT”. ELT Journal 66 (1): 62-70.

Byram, M. 1988. "Foreign language education and cultural studies". Language, Culture and Curriculum 1 (1): 15-31.

Byram, M. 1997. Teaching and Assessing Intercultural Communicative Competence. Clevedon: Multilingual Matters.

Byram, M. 2008. From Foreign Language Education to Education for Intercultural Citizenship: Essays and Reflections. Clevedon: Multilingual Matters.

Byram, M. 2014. "Twenty-five years on - from cultural studies to intercultural citizenship". Language, Culture and Curriculum 27 (3): 209-25.

Byram, M. and V. Esarte-Sarries. 1991. Investigating Cultural Studies in Foreign Language Teaching: A Book for Teachers. Clevedon: Multilingual Matters.

Byram, M. and C. Morgan. 1994. Teaching-and-Learning Language-and-Culture. Clevedon: Multilingual Matters.

Chen, Y. 2010. "The Semiotic construal of attitudinal curriculum goals: Evidence from EFL textbooks in China". Linguistics and Education 21 (1): 60-74.

Crystal, D. 2008. "Two thousand million?” English Today 24 (1): 3-6.

Holliday, A. 1999. "Small cultures". Applied Linguistics 20 (2): 237-64.

Kramsch, C. 1993. Context and Culture in Language Teaching. Oxford: Oxford University Press. 
Krippendorff, K. 2004. Content Analysis: An introduction to its methology. Thousand Oaks, CA: Sage.

Kumaravadivelu, B. 2008. Cultural globalization and language education. New Haven, CT: Yale University Press.

Lai, H. T. 2014. "Learning English as an international language: EFL learners' perceptions of cultural knowledge acquisition in the English classroom". Asian Social Science 10 (1): 1-11.

Larrea-Espinar, A. 2015. "El aprendizaje cultural en la enseñanza de inglés y su alcance en los libros de texto". Revista Española de Lingüistica Aplicada 28 (1): $145-168$.

Lee, K-Y. 2009. "Treating culture: What 11 high school EFL conversation textbooks in South Korea do". English Teaching: Practice and Critique 8 (1): 76-96.

McConachy, T. and K. Hata. 2013. "Addressing textbook representations of pragmatics and culture". ELT Journal 67 (3): 294-301.

McKay, S. L. 2002. Teaching English as an International Language: Rethinking Goals and Approaches. Oxford: Oxford University Press.

Méndez-García, M. 2005. "International and intercultural issues in English teaching textbooks: The case of Spain". Intercultural Education 16 (1): 57-68.

Mitchell, R. and F. Myles. 2004. Second language learning theories. London: Hodder Arnold.

Paige, R. M., Jorstad, H., Paulson, L., Klein, F. and J. Colby. 1999. "Culture learning in language education: A review of the literature". Culture as the core: Integrating culture into the language curriculum (CARLA Working Paper Series 15). Eds. R. Michael Paige, D. Lange and Y. Yershova. Minneapolis: The Center for Advanced Research on Language Acquisition, University of Minnesota. 1-73.

Peterson, B. 2004. Cultural Intelligence: A Guide to Working with People from Other Cultures. Yarmouth, ME: Intercultural Press.

Raigón-Rodríguez, A. and A. Larrea-Espinar. 2015. "General and Specific Culture Learning in EFL Textbooks Aimed at Adult Learners in Spain”. Studia Anglica Posnaniensia 50 (1): 5-25.

Risager, K. 1991. "Cultural references in European textbooks: an evaluation of recent tendencies". Mediating Languages and Cultures: Towards an Intercultural Theory of Foreign Language Education. Eds. D. Buttjes and M. Byram. Clevedon: Multilingual Matters. 180-192.

Risager, K. 2011. "The cultural dimensions of language teaching and learning". Language Teaching 44: 485-499. 
Saville-Troike, M. 2003. "Extending 'communicative' concepts in the second language curriculum". Culture as the core: perspectives of culture in second language learning. Eds. D. Lange and R. Michael Paige. Greenwitch, CT: Information Age Publishing. 3-17.

Shin, J., Zohreh, R. E. and W-C. Chen. 2011. "Presentation of local and international culture in current international English-language teaching textbooks". Language, Culture and Curriculum 24 (3): 253-268.

Weninger, C. and T. Kiss. 2013. "Culture in EFL textbooks: A Semiotic approach". TESOL Quaterly 47 (4): 694-716.

Weninger, C. and T. Kiss. 2015. "Analyzing culture in foreign/second language textbooks: methodological and conceptual issues”. Language, Ideology and Education: The Politics of Textbooks in Language Education. Eds. X. L. CurdtChristiansen and C. Weninger. London: Routledge. 50-66.

Wu, J. 2010. "A content analysis of the cultural content in the EFL textbooks". Canadian Social Science 6 (5): 137-44.

Yuen, Ka-Ming. 2011. "The representation of foreign cultures in English texbooks". ELT Journal 65 (4): 458-66. 